\title{
Cyclin D1 Expression in Odontogenic Cysts
}

\section{Odontojenik Kistlerde Siklin D1 Ekspresyonu}

\author{
Nasim TAGHAVI' ${ }^{\text {, Shirin MODABBERNIA }}{ }^{\text {, Alireza AKBARZADEH }}{ }^{2}$, Samad SAJJADI ${ }^{3}$ \\ Department of ${ }^{1}$ Oral and Maxillofacial Pathology, ${ }^{2}$ Biostatistics, ${ }^{3}$ Paramedical Sciences, Shahid Beheshti University of Medical Science, TEHRAN, IRAN
}

\section{ABSTRACT}

Objective: In the present study expression of cyclin D1 in the epithelial lining of odontogenic keratocyst, radicular cyst, dentigerous cyst and glandular odontogenic cyst was investigated to compare proliferative activity in these lesions.

Material and Method: Immunohistochemical staining of cyclin D1 on formalin-fixed, paraffin-embedded tissue sections of odontogenic keratocysts $(n=23)$, dentigerous cysts $(n=20)$, radicular cysts $(n=20)$ and glandular odontogenic cysts $(n=5)$ was performed by standard EnVision method. Then, slides were studied to evaluate the following parameters in epithelial lining of cysts: expression, expression pattern, staining intensity and localization of expression.

Results: The data analysis showed statistically significant difference in cyclin D1 expression in studied groups $(\mathrm{p}<0.001)$. Assessment of staining intensity and staining pattern showed more strong intensity and focally pattern in odontogenic keratocysts, but difference was not statistically significant among groups respectively $(p=0.204$, 0.469). Considering expression localization, cyclin D1 positive cells in odontogenic keratocysts and dentigerous cysts were frequently confined in parabasal layer, different from radicular cysts and glandular odontogenic cysts. The difference was statistically significant $(\mathrm{p}<0.01)$

Conclusion: Findings showed higher expression of cyclin D1 in parabasal layer of odontogenic keratocyst and the entire cystic epithelium of glandular odontogenic cysts comparing to dentigerous cysts and radicular cysts, implying the possible role of G1-S cell cycle phase disturbances in the aggressiveness of odontogenic keratocyst and glandular odontogenic cyst.

Key Words: Cyclin D1, Odontogenic cysts, Immunohistochemistry

\section{Öz}

Amaç: Mevcut çalışmada odontojenik keratokist, radiküler kist, dentijeröz kist ve glandüler odontojenik kist epitelinde siklin D1 ekspresyonu, bu lezyonlardaki proliferatif aktiviteyi karşılaştırmak üzere incelendi.

Gereç ve Yöntem: Siklin D1'in formalinle fikse edilmiş parafine gömülü odontojenik keratokist $(n=23)$, dentijeröz kist $(n=20)$, radiküler kist $(n=20)$ ve glandüler odontojenik kist $(n=5)$ doku kesitlerinde immünohistokimyasal boyanması standart EnVision yöntemi ile yapıldı. Sonra, lamlar kist epitelinde şu parametrelerin değerlendirilmesi için incelendi: ekspresyon, ekspresyon paterni, boyanma şiddeti ve ekspresyon lokalizasyonu.

Bulgular: Veri analizi, çalışılan gruplarda siklin D1 ekspresyonu açısından istatistiksel olarak anlamlı fark gösterdi $(\mathrm{p}<0,001)$. Boyanma şiddeti ve boyanma paterninin değerlendirilmesi odontojenik keratokistlerde daha şiddetli ve fokal bir patern gösterirken, fark gruplar arasında istatistiksel olarak anlamlı değildi $(p=0,204,0,469)$. Ekspresyon lokalizasyonu açısından odontojenik keratokistler ve dentijeröz kistlerde siklin D1 pozitif hücreleri radiküler kistler ve glandüler odontojenik kistlerden farklı olarak sıklıkla parabazal tabakada bulunmaktaydı. Fark istatistiksel olarak anlamlıyd $1(\mathrm{p}<0,01)$.

Sonuç: Sonuçlar dentijenöz kistler ve radiküler kistlere göre odontojenik keratokist parabazal tabakası ve glandüler odontojenik kistlerin tüm kistik epitelinde daha yüksek siklin D1 ekspresyonu gösterdi ve bu durum odontojenik keratokist ve glandüler odontojenik kistin agresifliğinde G1-S hücre döngüsü fazı bozukluklarının olası bir rolünü düşündürdü.

Anahtar Sözcükler: Siklin D1, Odontojenik kistler, İmmünohistokimya

\section{INTRODUCTION}

Odontogenic cycts are subclassified as developmental or inflammatory in origin with variable clinical and biological behaviors. Radicular cyst (RC) is an inflammatory odontogenic cyst which derived from the epithelial rest of malassez, whereas dentigerous cyst (DC), odontogenic keratocyst (OKC) and glandular odontogenic cyst (GOC)

(Turk Patoloji Derg 2013, 29:101-107)

Received : 03.10.2012 Accepted : 16.03.2013 are developmental in origin. Amongst these, odontogenic keratocyst and glandular odontogenic cyst show aggressive behavior specially OKC. OKC recently classified by World Health Organization as keratocystic odontogenic tumor, comprises $3 \%$ to $11 \%$ of odontogenic cysts which arises from dental lamina, although origin of this cyst from extension of basal cells of the overlying epithelium has also been suggested (1).
Correspondence: Nasim TAGHAVI

Department of Oral and Maxillofacial Pathology, Shahid Beheshti University of Medical Science, TEHRAN, IRAN

E-mail: nasim.taghavi@yahoo.com Phone: +98912 1815387 
It is known that OKC shows aggressive behavior with higher rates of recurrence than other types of odontogenic cysts, as well as a tendency to invade adjacent tissues (2). Numerous studies intended to identify the precise nature and special characteristics of OKC. According to these data the characteristics of OKC may be related to proliferative activity in epithelial lining or enzymatic activity in fibrous wall (1).

Some of these findings could support the theory that OKCs are neoplastic in origin, but other results clearly indicate that these lesions are developmental odontogenic cysts with some neoplastic properties due to high intrinsic growth potential $(3,4)$. Some authors reported an abnormal expression of tumor suppressor genes and oncogenes in OKC such as PTCH gene (2).

Transition between different stages of cell cycle is regulated at check points. Several check points are regulated by cyclin dependent kinases (CDKs) and their activating partners, the cyclins. Cyclin D1 gene (CCDN1) is located on chromosome 11q13, encodes a critical cell cycle regulatory protein (Cyclin D1) that drives the cell cycle from G1 to $S$ phase (5). Amplification and over expression of CCND1 has been reported in various carcinoma $(6,7,8,9,10,11,12)$, so the study of cyclin D1 expression may improve our knowledge about the biological substrate of OKC and GOC behavior .

Based on this hypothesis, in the present study, expression of cyclin D1 in the epithelial lining of odontogenic keratocyst and three other odontogenic cysts including radicular cyst, dentigerous cyst and glandular odontogenic cyst in order to evaluate and compare proliferative activity in these cystic lesions in different layers of epithelium was undertaken.

\section{MATERIALS and METHODS}

\section{Sample collection}

After reviewing clinical information and histologic findings, a total of 68 odontogenic cysts consisting parakeratinized OKCs $(n=23)$, DCs $(n=20)$, RCs $(n=20)$ and GOCs $(n=5)$ were collected from paraffin-embedded blocks of Oral and Maxillofacial Pathology Department, Beheshti University of Medical Sciences, Tehran, Iran.

Since many studies showed that proliferative activity in OKCs associated with Gorlin syndrome (syndromic OKC) is higher than sporadic OKCs, they were excluded from the study. Inflammatory cysts except for radicular cysts because of probable effect of inflammation on proliferative activity were not included the samples either.

\section{Immunohistochemistry}

Expression of cyclin D1 was determined immunohistochemically using a standard EnVision method. In brief, all of the samples were fixed in $10 \%$ formalin, and embedded in paraffin. Histologic sections were cut at $4 \mathrm{~m}$ and mounted on poly-L-lysine coated slides. Following dewaxing and rehydration, antigen retrieval was performed by heating in microwave oven for 20 minutes in a freshly prepared, citrate buffer solution at $\mathrm{PH}=6$. After cooling to room temperature and rinsing in phosphate buffer saline (PBS), incubation with $0.3 \%$ hydrogen peroxide for 20 minutes was done to block the endogenous peroxidase activity. Cyclin D1 staining was performed using monoclonal mouse antibody (N1619, Dako, Denmark) for 1 hour according to Dako instruction. They were then rinsed in PBS and bound antibody was detected using EnVision polymer technology (K4081, DAKO) for 30 minutes. Staining was developed with 3-3 diaminobenzidine (DAB) for 5 minutes and then lightly counterstained with Mayer's hematoxyline and mounted. Tissue sections of the oral squamous cell carcinoma were considered as positive control. For negative control PBS was used instead of specific antibody. All slides were reviewed by two pathologists blindly. Assessing the expression of cyclin D1 in this study were classified as positive which showed nuclear staining in epithelial cells, whereas others were defined as negative. The positive cases were classified to additional categories, focal and diffuse expression (3). The slides were also evaluated for intensity of staining as mild, moderate and strong. Moreover, the epithelial layers predominantly containing the positive cells were noted in each group.

\section{Statistical analysis}

Analysis of the data was performed using Statistical Package for Social Sciences (SPSS software) (SPSS ${ }^{\circledR}$ Inc, Chicago, IL, USA) version 14.0. The Kruskal-Wallis test was used for ordinal variable. Fisher's exact test was performed to compare cyclin D1 expression among groups. $\mathrm{P}<0.05$ was regarded as statistically significant.

\section{RESULTS}

Table I shows that out of 68 selected cases, most of them were located in mandible $(n=52)$. Mean age in OKCs, DCs, RCs and GOCs was 34, 30, 38 and 36 years respectively. The lesions were seen more in male $(n=44)$.

Results of cyclin D1 immunostaining in selected odontogenic cysts are as follows: 
Odontogenic keratocyst: As Table II shows, cyclin D1 expressed in 20 (87\%) cases (Figure 1A, B). Immunoreactivity in most of the cases $(n=16)$ was restricted to the parabasal layer with strong intensity $(n=11)$ and focally pattern $(n=12)$. Only one case showed positivity from parabasal to superficial layer.

Dentigerous cyst: In DCs, cyclin D1 was detected in 5(25\%) cases (Figure 2) with focally pattern of staining. Positive cells similar to OKCs were limited more in parabasal layer but it was about $1 / 2$ of those in OKCs. Staining intensity was mild to moderate (Table II).

Radicular cyst: Cyclin D1 was discernible in $6(30 \%)$ cases of RCs (Figure 3) frequently in parabasal and superficial layer (4 of 6 cases). Two (33.3\%) cases only showed immunostaining in superficial layer. Focal and diffuse pattern of staining were equally observed in positive RCs. Strong intensity was visible in $3(50 \%)$ cases (Table II).

Glandular odontogenic cyst: In few samples of GOCs, cyclin D1 positivity was 60\% (3 of 5) with focally staining pattern in all cases. Strong intensity was evident in $2(66.7 \%)$ cases (Figure 4) with extension over the entire cystic epithelium (Table II).

The data analysis showed statistically significant difference in cyclin D1 expression in studied groups ( $<<0.001$,Fisher's exact test). Moreover, the difference in cyclin D1 expression between OKCs and RCs as well as OKCs and DCs was significant $(\mathrm{p}<0.001)$ but the difference was not observed between OKCs and GOCs ( $\mathrm{p}=0.10)$, DCs with RCs ( $\mathrm{p}=0.640)$, RCs with GOCs $(\mathrm{p}=0.243)$ and DCs with GOCs $(\mathrm{p}=0.283)$.

Table I: Demographic information of studied groups

\begin{tabular}{|l|c|c|c|c|c|c|}
\hline \multirow{2}{*}{} & \multirow{2}{*}{ No } & \multirow{2}{*}{ Mean age (SD) } & \multicolumn{2}{|c|}{ Gender } & \multicolumn{2}{|c|}{ Site } \\
\cline { 4 - 7 } & & & Male & Female & Mandible & Maxilla \\
\hline Odontogenic keratocyst & 23 & $34(3.25)$ & 13 & 10 & 20 & 3 \\
\hline Dentigerous cyst & 20 & $30(1.25)$ & 14 & 6 & 13 & 7 \\
\hline Radicular cyst & 20 & $38(2.5)$ & 13 & 7 & 16 & 4 \\
\hline Glandular odontogenic cyst & 5 & $36(4.25)$ & 4 & 1 & 3 & 2 \\
\hline
\end{tabular}

Table II: Distribution of expression, staining pattern, staining intensity and staining localization of cyclin D1 in odontogenic cysts

\begin{tabular}{|l|c|c|c|c|c|}
\hline & OKC & DC & RC & GOC & P value \\
\hline Expression & $\mathrm{n}(\%)$ & $\mathrm{n}(\%)$ & $\mathrm{n}(\%)$ & $\mathrm{n}(\%)$ & \\
\hline Expression pattern & $20(87 \%)$ & $5(25 \%)$ & $6(30 \%)$ & $3(60 \%)$ & $<0.001$ \\
\hline Focallly & & & & & 0.204 \\
\hline Diffuse & $12(52 \%)$ & $5(25 \%)$ & $3(15 \%)$ & $3(60 \%)$ & \\
\hline Staining intensity & $8(34 \%)$ & $0(0 \%)$ & $3(15 \%)$ & $0(0 \%)$ & 0.469 \\
\hline Mild & & & & & $0(0 \%)$ \\
\hline Moderate & $2(10 \%)$ & $1(20 \%)$ & $3(50 \%)$ & $1(33 \%)$ & \\
\hline Strong & $7(35 \%)$ & $3(60 \%)$ & $3(50 \%)$ & $2(66.7)$ & \\
\hline Staining localization & $11(55 \%)$ & $1(20 \%)$ & $0(0 \%)$ & & \\
\hline Basal & $1(5 \%)$ & $1(20 \%)$ & $1(16.7 \%)$ & $0(0 \%)$ & \\
\hline Parabasal & $16(80 \%)$ & $2(40 \%)$ & $0(0 \%)$ & $1(33.3 \%)$ & \\
\hline Basal\&parabasal & $2(10 \%)$ & $1(20 \%)$ & $0(0 \%)$ & $0(0 \%)$ & \\
\hline Superficial & $0(0 \%)$ & $0(0 \%)$ & $2(33.3 \%)$ & $0(0 \%)$ & \\
\hline Superficial\&parabasal & $1(5 \%)$ & $1(20 \%)$ & $2(33.3 \%)$ & $0(0 \%)$ & \\
\hline All layers & $0(0 \%)$ & $0(0 \%)$ & $1(16.7 \%)$ & $2(66.7 \%)$ & \\
\hline
\end{tabular}

$\mathrm{P}<0.05$ is significant

(DC) dentigerous cyst, (RC) radicular cyst, (OKC) odontogenic keratocyst and (GOC) glandular odontogenic cyst. 

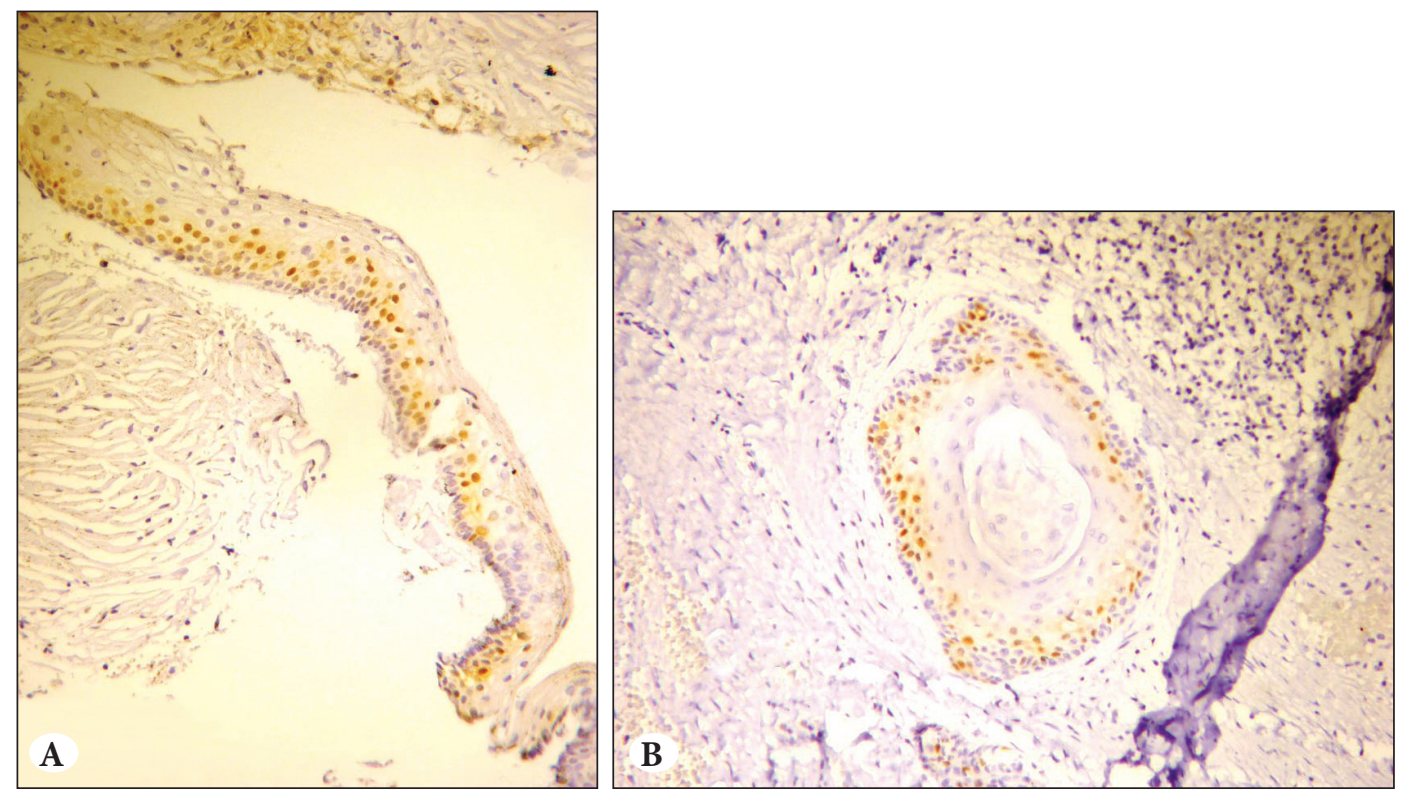

Figure 1: $(A, B)$ Cyclin D1 expression with strong intensity in odontogenic keratocyst (x40).

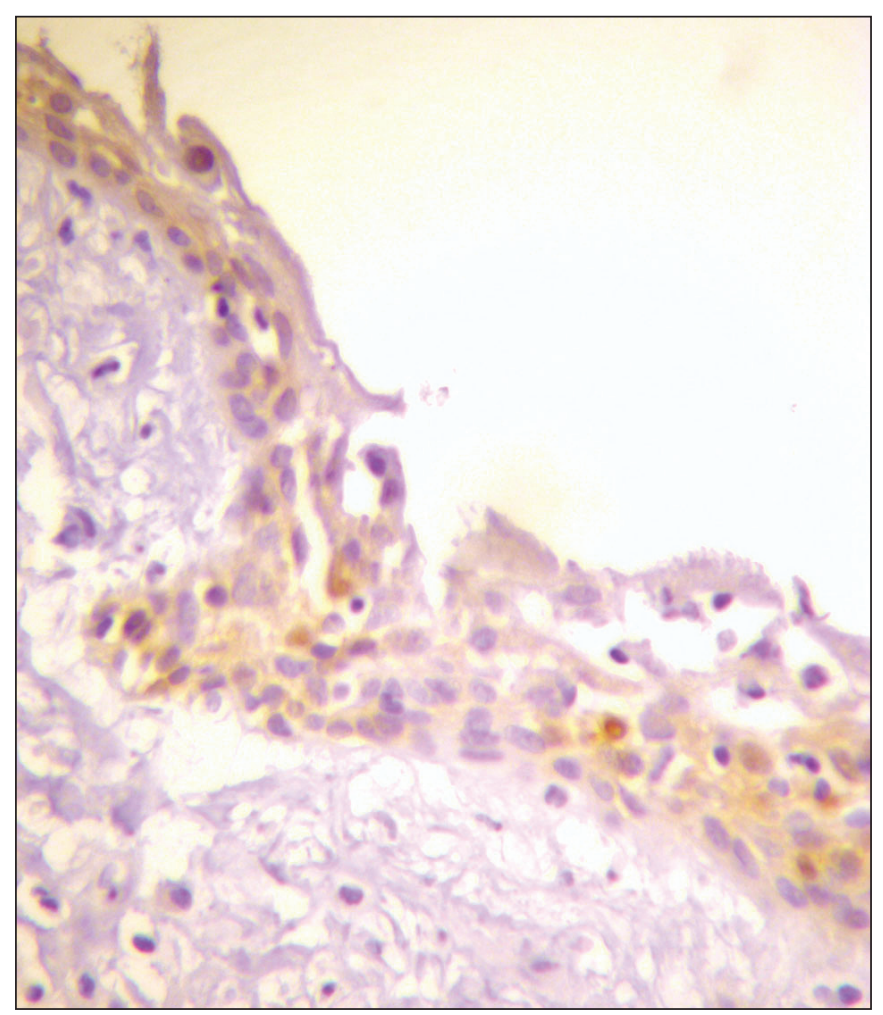

Figure 2: Cyclin D1 expression with moderate intensity in dentigerous cyst (x40).

As previously mentioned OKCs and DCs showed positive staining mainly in parabasal layer which was different from RCs and GOCs. Statistically significant difference was also observed in expression localization of cyclin D1 among four groups ( $\mathrm{p}<0.01$, Fisher's exact test).

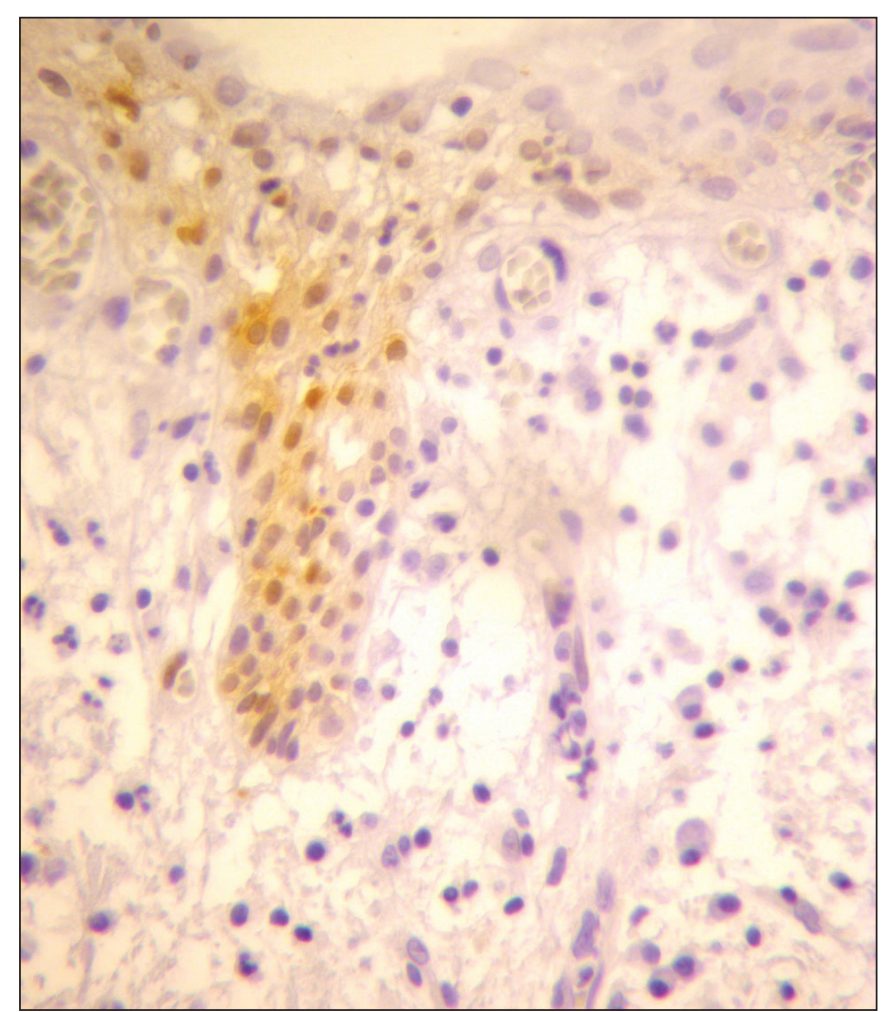

Figure 3: Cyclin D1 expression with moderate intensity in radicular cyst (x100).

Assessment of staining pattern and staining intensity using Kruskal-Wallis test showed no significant difference in expression pattern $(\mathrm{p}=0.204)$ as well as staining intensity $(\mathrm{p}=0.469)$ across all groups. 


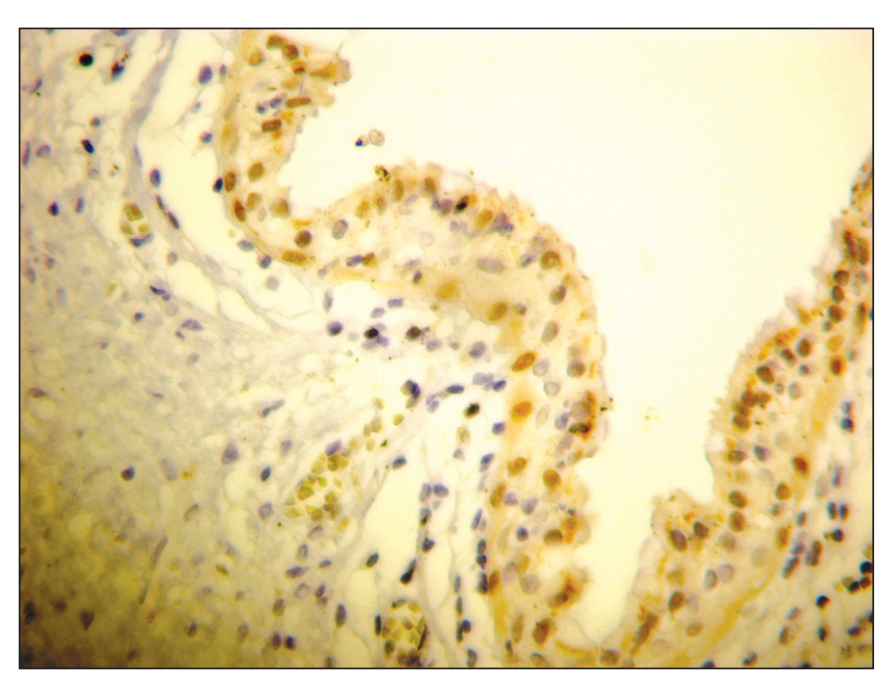

Figure 4: Cyclin D1 expression with strong intensity in glandular odontogenic cysts (x100).

\section{DISCUSSION}

Cyclin $\mathrm{D} 1$ is one of the $\mathrm{Rb}$ pathway proteins with oncogene properties which controls G1-S transition. Elevated levels of this protein might allow cells to escape from the cell cycle check point control and play an important role in tumorigenesis $(13,14,15)$. Expression of cyclin D1 is detected in various types of malignant tumor whereas in normal tissue and benign tumors is negative or weakly expressed $(13,16,17)$. To date, studies related to cyclin D1 expression in odontogenic cysts specially GOC are scarce and mainly have been focused on expression of other proliferation markers in OKC to compare with other cysts and odontogenic tumors as well as sporadic OKC with recurrent and syndromic ones $(3,13)$.

In this study with respect to different clinical behavior and aggressiveness of odontogenic cysts, we employed immunohistochemical staining to evaluate cyclin D1 expression in epithelial lining of OKC, DC, RC and GOC to demonstrate differences in expression of this protein.

We observed a decreased staining positivity for cyclin D1 in the following order: OKCs (87\%), GOCs (60\%), RCs (30\%), and DCs (25\%). It was detected mostly in the parabasal layer of OKCs and DCs in contrast to what happens in RCs and GOCs. This is in line with Juan-Carlos de-Vicent, and Kenji Kimi's studies $(3,13)$. Kimi et al. investigated immunohistochemical expression of cyclin D1 and p16 in sporadic, recurrent and syndromic OKC. Similar to our study cyclin D1 was detected in parabasal layer of OKC with higher expression in syndromic OKC. Lo Muzio et al. compared cyclin D1 expression in sporadic OKCs and OKCs associated with Gorlin syndrome. On the contrary, they observed cyclin D1 expression just in syndromic
OKCs not in sporadic ones (18). However, other studies showed higher expression of cyclin D1 in syndromic OKCs comparing to sporadic OKCs which can lead to disruption of cellular proliferation control system and more aggressive clinical behavior, but none of them reported the lack of cyclin D1 expression in sporadic OKC. The discrepancy between findings may be due to various laboratory methods and used antibody. In Lo Muzio's study clone 5D4, diluted 1:800 was used while we used the clone DCS- 6 and ready to use antibody.

Evaluation of staining pattern and intensity in current study showed no significant difference among groups. This result is in agreement with Juan-Carlos de-Vicente's (3) report who examined cyclin D1 expression in OKCs in comparison with other lesions including ameloblastoma. It should be pointed out that our study contains many more cases than those of carlos - de -Vicente's research.

In most OKCs and DCs, cyclin D1 was detected in parabasal layer and in consistent with previous research $(3,13)$ seen more predominant in OKCs comparing DCs whereas in GOCs most of the cases showed expression over the cystic epithelium. These results may imply different proliferative activity in the epithelial layers in each group. Besides, it can justify the aggressive behavior of GOCs which is somehow similar to OKCs are only different in staining localization. Significant difference just in staining localization suggests the different proliferative compartment and growth pattern in these lesions but, since this is the first study related to cyclin D1 expression in GOCs, Further studies using greater number of cases "particularly focusing on aggressive behavior and clinical findings" seems essential to get more insights on these issues.

It is noticeable that in one case of radicular cyst cyclin D1 expression was also seen in all layers of epithelial lining. Bando et al. showed that cytokines and growth factors released by inflammatory cells present in connective tissue can stimulate epithelial proliferation in RC and more intense inflammation may cause greater proliferative activity (19). Therefore, cyclin D1 expression in all layers may be related to the intensity of inflammation in cyst wall.

Other studies by evaluation of P53, P63, Ki-67, COX-2, IPO-38 and PCNA immunostaining in odontogenic cysts "to compare their proliferative activity" have also shown the higher expression of mentioned markers in parabasal layer of OKCs in contrast to DCs, RCs or normal mucosa seen in basal layer $(18,19,20,21,22,23,24,25)$.

Taken together, regarding to all of the reports and studies in this field, it seems that OKC epithelium lining has a 
parabasal proliferation compartment and some intrinsic growth potential which are not seen in dentigerous and radicular cyst and different from GOC. Here we should point out that thus far the emphasis in research have been concentrated on the epithelium itself, only occasional passing reference to underlying connective tissue stroma like assessment of extracellular matrix components (24) and needs more investigation.

In conclusion, the results showed that cyclin D1 expression was higher in OKCs and GOCs respectively comparing to DCs and RCs. Immunostaining was present in parabasal layer in most cases of OKCs whereas in GOCs positive cells was seen in all layers. These findings could help us to explain the differences in the clinical behavior of OKCs and GOCs, pointing to different proliferative compartment and an abnormal control cell cycle leading to an intrinsic growth potential.

\section{ACKNOWLEDGMENTS}

This work was excerpted from dissertation NO 2983, Dental Faculty, Beheshti University of Medical Sciences, Tehran, Iran. This work has been supported financially by research center of shahid Beheshti dental faculty.

\section{REFERENCES}

1. Neville BW, Damn DD, Allen CM, Bouquot JE: Oral and Maxillofacial pathology. 3th ed., China, Saunders Elsevier, 2009

2. Chirapathomsakul D, Sastravaha P, Jansisyanont P: A review of OKC and the behavior of recurrences. Oral Surg Oral Med Oral Pathol Oral Radiol Endod 2006, 101:5-9

3. de Vicente JC, Torre-Iturraspe A, Gutiérrez AM, LequericaFernández P: Immunohistochemical comparative study of odontogenic keratocysts and other odontogenic lesions. Med Oral Patol Oral Cir Bucal 2010, 15:709-715

4. Shear M: The aggressive nature of the odontogenic keratocyst; Is it benign cystic neoplasm? Oral Oncology 2002, 38:323-331

5. Robbins S, Cortan R: Pathologic basis of disease. 7th ed., Philadelphia, Saunders, 2005

6. Miyamoto R, Uzawa N, Nagaoka Sh, Hirata Y, Amagasa T: Prognostic significance of cyclin D1 amplification and overexpression in oral squamous cellcarcinomas. Oral Oncology 2003, 39:610-618

7. Quelle DE, Ashmun RA, Shurtleff SA, Kato JY, Bar-Sagi D, Roussel MF, Sherr CJ: Overexpression of mouse D-type cyclins accelerates G1 phase in rodent fibroblasts. Genes Dev 1993, 7:1559-1571

8. Nakashima T, Clayman GL: Antisense inhibition of cyclin D1 in human head and neck squamous cell carcinoma. Arch Otolaryngol Head Neck Surg 2000, 126:957-961
9. Matthias C, Branigan K, Jahnke V, Leder K, Haas J, Heighway J, Jones PW, Strange RC, Fryer AA, Hoban PR: Polymorphism within the cyclin D1 gene is associated with prognosis in patients with squamous cell carcinoma of the head and neck. Clin Cancer Res 1998, 4:2411-2418

10. Mineta H, Miura K, Takebayashi S, Ueda Y, Misawa K, Harada H, Wennerberg J, Dictor M: Cyclin D1 overexpression correlates with poor prognosis in patients with tongue squamous cell carcinoma. Oral Oncol 2000, 36:194-198

11. Keum JS, Kong G, Yang SC, Shin DH, Park SS, Lee JH, Lee JD: Cyclin D1 overexpression is an indicator of poor prognosis in resectable non-small cell lung cancer. Br J Cancer 1999, 81: 127-132

12. Toyoda H, Nakamura T, Shinoda M, Suzuki T, Hatooka S, Kobayashi S, Ohashi K, Seto M, Shiku H, Nakamura S: Cyclin D1 expression is useful as a prognostic indicator for advanced esophageal carcinomas, but not for superficial tumors. Dig Dis Sci 2000, 45:864-869

13. Kimi K, Kumamoto H, Ooya K, Motegi K: Immunohistochemical analysis of cell-cycle-and apoptosis-related factors in lining epithelium of odontogenic ketarocysts. J Oral Pathol Med 2001, 30:434-442

14. Xiong Y, Hannon Gj, Zhang H, Casso D, Kobayashi R, Beach D: P21 is a universal inhibitor of cyclin kinases. Nature 1993, 366:701-704

15. Donnellan R, Chetty R: Cyclin D1 and human neoplasia. Mol Pathol 1998, 51:1-7

16. Jiang W, Zhang YJ, Kahn SM, Hollstein MC, Santella RM, Lu SH, Harris CC, Montesano R, Weinstein IB: Altered espression of the cyclin D1 and retinoblastoma genes in human esophageal cancer. Proc Natl Acad Sci USA 1993, 90:9026-9030

17. Gillett C, Fantl V, Smith R, Fisher C, Bartek J, Dickson C, Barnes D, Peters G: Amplification and overexpression on cyclin D1 in breast cancer detected by immunohistochemical staining. Cancer Res 1994, 54:1812-1817

18. Lo Muzio L, Santarelli A, Caltabiano R, Rubini C, Pieramici T, Fior A, Trevisiol L, Carinci F, Leonardi R, Bufo P, Lanzafame S, Piattelli A: P63 expression in odontogenic cycts. Int J Oral Maxillofac Surg 2005, 34:668-673

19. Bando Y, Henderson B, Meghji S, Poole S, Harris M: Immunohistochemical localization of inflammatory cytokines and vascular adhesion receptors in radicular cysts. J Oral Pathol 1994, 78:511-521

20. Kolár Z, Geierová M, Bouchal J, Pazdera J, Zboril V, Tvrdý $P$ : Immunohistochemical analysis of the biological potential of odontogenic keratocysts. J Oral Pathol Med 2006, 35:75-80

21. Kim DK, Ahn SG, Kim J, Yoon JH: Comparative Ki-67 expression and apoptosis in the odontogenic keratocyst associated with or without an impacted tooth in addition to unilocular and multilocular varieties. Yonsei Medical Journal 2003, 44: 841-846

22. de Oliveira MG, Lauxen Ida S, Chaves AC, Rados PV, Sant'Ana Filho M: Immunohistochemical analysis of the patterns of P53 and PCNA expression in odontogenic cystic lesions. Med Paral Patol Oral Cir Bucal 2008, 13: E275-280 
23. Mendes RA, Carvalho JF, van der Waal I: A comparative immunohistochemical analysis of COX-2, p53, and Ki-67 expression in keratocystic odontogenic tumors. Oral Surg Oral Med Oral Pathol Oral Radiol Endod 2011, 111: 333-339

24. Baghaei F, Eslami M, Sadri D: Evaluation of Ki-67 antigen and protein P53 expression in orthokeratinized and parakeratinized keratocyst. Journal of Dentistry Tehran University of Medical Sciences 2004, 1: 53-58

25. Amorim RF, Godoy GP, Galvão HC, Souza LB, Freitas RA: Immunohistochemical assessment of extracellular matrix components in syndrome and non-syndrome odontogenic keratocysts. Oral Dis 2004, 10:265-270 